\section{Bush's 'parting gifts'}

Suzanne J Farley

As head of the US administration that has issued more regulations than any other, President George W Bush sought to safeguard his legacy in a final flurry of regulatory zeal. In the run-up to the handover to President Obama, the outgoing Republican administration rushed to enact several 'midnight' policy changes affecting the environment, firearm use, consumer and employee protection, and national security. Health care was also targeted. In what Democrat Senator Henry Waxman described as "a long-coveted parting gift" to pharmaceutical companies, the FDA has relaxed the restrictions on dissemination of information about off-label uses for drugs and devices.

Defined as "the practice of prescribing pharmaceuticals for a purpose outside the scope of a drug's approved label" (Wikipedia, http:// en.wikipedia.org/wiki/Off-label_use), there have been few reliable and comprehensive analyses of the extent of off-label use. Best estimates are that it accounts for up to a fifth of all prescriptions (Radley DC et al. [2006] Arch Intern Med 166: 1021-1026). The proportion is markedly higher in pediatrics and oncology. The author of a recent review found that-at 58\% - hormonerefractory prostate cancer had the highest rate of off-label drug use in the anticancer field. Bladder cancer and renal cell carcinoma were two other indications for which the use of unapproved treatments is extremely common (Levêque $D$ [2008] Lancet Oncol 9: 1102-1107).

Physicians who prescribe drugs and devices off-label are not breaking the law. By contrast, until the new guidance was issued in January of this year, it had been illegal for manufacturers to promote off-label use of their products, and the FDA had been cracking down on this practice. In fact, in the same month, Eli Lilly was hit with the largest individual corporate penalty in history. The firm has agreed to a US\$1.4 billion settlement for marketing olanzapine (Zyprexa ${ }^{\circledR}$ ), approved as an antipsychotic, for off-label use in a range of other conditions, such as depression and dementia.

\section{...the FDA has relaxed the restrictions on dissemination of information about off-label uses for drugs and devices}

SJ Farley is Deputy Editor of Nature Clinical Practice Urology.

\section{Competing interests}

The author declared no competing interests.

www.nature.com/clinicalpractice doi:10.1038/ncpuro1321
The FDA's about-face is in regard to the distribution of scholarly articles. The new Good Reprint Practices guidelines permit sales reps to give doctors literature that supports unapproved uses of products. It is hoped that inappropriately aggressive promotion will, however, be prevented by the imposition of several conditions. Reps cannot discuss articles with prescribers during sales visits, and distribution from conference booths is prohibited. The new guidance also strives to ensure the quality and unbiased nature of the distributed literature. Articles must have been peer-reviewed, their content not have been 'significantly influenced' by the manufacturer, be clearly marked as discussing off-label use, and be distributed together with the FDAapproved labeling as well as publications that have drawn contradictory conclusions.

Stating that it "...recognize[s]...the important public health and policy justification supporting dissemination of truthful and non-misleading medical journal articles...on unapproved uses of approved drugs and...medical devices...", is the FDA acknowledging the reality of current prescribing practices and the prohibitive cost of seeking formal approval for new drug uses, rather than giving big pharma a politically motivated "gift"? Asked whether efficacy requirements should be imposed on off-label uses, an overwhelming majority of the 500 physicians who responded to a recent online survey answered 'no' (Klein DB and Tabarrok A [2008] Am J Econ Sociol 67: 743-775). Interestingly, most also responded in the negative when asked whether efficacy requirements for original intended uses should be dropped. Obviously, some data are better than none.

So, when you're next cornered by a sales rep, you might be pleasantly surprised to receive a copy of a high-quality paper that is of real practical value. Best not get too used to it, though. Incoming leaders generally take a good hard look at their predecessors' 'midnight' regulations. President Obama might repeal the new guidance as part of his grand plan for health-care reform. 